\title{
Destructive Defeat and Justificational Force: The Dialectic of Dogmatism, Conservatism, and Meta-Evidentialism
}

\section{Evidential defeat}

One part of your evidence can conflict with another part. Suppose at $\mathrm{t}_{1}$, your total evidence justifies you in believing $p$. At a later time, $\mathrm{t}_{2}$, you acquire additional evidence. Now your total evidence no longer justifies you in believing $p$. When this happens, the additional evidence you have acquired is a defeater. It defeats those parts of your evidence that, at $\mathrm{t}_{1}$, justify you in believing $p$ but no longer justify you in believing $p$ at $\mathrm{t}_{2}{ }^{1}$ It is customary to distinguish between two kinds of defeaters. Suppose that one part of your total evidence, $\mathrm{E}_{1}$, supports believing $p$. You acquire a new bit of evidence, $\mathrm{E}_{2}$. If $\mathrm{E}_{2}$ supports believing $\sim p, \mathrm{E}_{2}$ is a rebutting defeater. If $\mathrm{E}_{2}$ supports believing that there is no reliable connection between $\mathrm{E}_{1}$ and the truth of $p$, then $\mathrm{E}_{2}$ is an undermining defeater. ${ }^{2}$ Consider a couple of examples to illustrate the difference.

Suppose, in a wide variety of circumstances and over a long period of time, all swans you have observed are white. That's inductive evidence for believing that all swans are white. But now you are looking at a black swan. Your observation of the black swan justifies you in believing the negation of all swans are white. It is a rebutting defeater of your inductive evidence in support of the generalization that all swans are white. Now suppose that you have observed many swans in your home town but never anywhere else. They have all been white. You recognize that, being limited to your home town, your inductive sample is not representative. This recognition does not justify you in believing the negation of all swans are white, but it does justify you in believing that your inductive sample is not a reliable basis for believing that all swans are white. It therefore is an undermining defeater of your inductive evidence:

Here is another example of an undermining defeater. Suppose there is a red looking table before you. Let 'Red' stand for the proposition that the table is red. Since the table looks red, you are inclined to believe Red. Suppose further you observe that red light is illuminating the table. Your observation undermines your visual experience-the table's looking red to you-

\footnotetext{
${ }^{1}$ Roderick Chisholm and John Pollock were the first to highlight the importance of defeaters. See Chisholm 1966, p. 48, Pollock 1974 p. $40 \mathrm{ff}$ and Pollock 1986, p. 38f.

2 See Pollock 1974, p. 40.
} 
as evidence for believing Red. It justifies you in believing that, under the circumstances, the table's looking red to you is not a reliable indication of actual redness.

This example raises an important question that has received little attention in the literature. Exactly how does your observation of red light undermine and take away your justification for believing Red? One option is that, even though you would not be justified in believing Red, the table's looking red to you continue to give you justification for believing Red. Another option is that, after noticing the red light, the table's looking red to you completely ceases to give you justification for believing Red. According to the first option, your observation of red light merely undermines but does not destroy your visual experience of redness as a source of justification. According to the second option, the observation of red light undermines and thereby destroys your visual experience of redness as a source of justification. According to the first option, the observation of red light is a mere underminer. According to the second option, it is a destructive underminer.

A proper appreciation of the difference between mere undermining and destructive undermining requires paying close attention to two important distinctions. The first is that between some-things-considered (stc) and all-things-considered (atc) justification. Suppose your total evidence includes one bit, $\mathrm{E}_{1}$, that supports believing $p$, and another bit, $\mathrm{E}_{2}$, that supports believing $\sim p$. In a situation like that, you have stc, not atc, justification for believing $p$ (as well as for believing $\sim p$ ). The second distinction is that between having justification for believing $p$ and being justified in believing $p$. The former is typically referred to as propositional, the latter as doxastic, justification. Whereas doxastic justification entails propositional justification, the latter does not entail the former. It is possible, for at least three reasons, to have justification for believing $p$ without being justified in believing $p$. First, one's justification for believing $p$ might be defeated. Second, one's belief that $p$ might not be properly based on one's justification for $p$. Third, even though one has justification for believing $p$, one might not acquire the belief that $p$ because one's interest and attention is directed elsewhere.

Note the way the two distinctions are related. Doxastic justification-a belief's being justified-is always atc justification. It would be odd to describe a belief as being stc but not atc justified. A belief either is, or is not, justified. It follows that the kind of justification that is either merely stc or atc is propositional justification. If one has justification for believing $p$ that comes from evidence $E$ but $E$ is defeated, then one has stc but not atc justification for 
believing $p$. If, on the other hand, $E$ is undefeated, then one has not merely stc but also atc justification for believing $p$.

In this paper, I am concerned with a species of propositional justification: the kind of justification perceptual experiences give us for believing propositions about the external world. Since propositional justification can be either stc or atc, when I say, for example, "your perceptual experience as of $p$ gives you justification for believing $p$," nothing is implied about whether you actually believe that $p$, or whether your belief that $p$ is justified all things considered. The claim is merely that, by virtue of having this perceptual experience, you have at least some degree of justification for believing $p$.

Let us now return to the example of the red-looking table. Your observation of red light is an undermining defeater, and what is being undermined is the table's looking red as justification for believing Red. Exactly how is your visual experience of redness undermined? The two options we considered above provide us with alternative ways to answer this question.

Mere undermining: The observation of red light merely undermines but does not destroy your visual experience of redness as justification for believing Red. You continue to have stc justification, but you fail to have atc justification, for believing Red. If you were to believe that the table is red, your belief would be unjustified. Doxastic justification is prevented, propositional justification is merely undermined. Destructive Undermining: The observation of red light undermines and destroys your visual experience of redness as justification for believing Red. You have no justification at all for believing Red. Both doxastic justification and propositional justification are destroyed.

Evidential defeat can undermine and thereby destroy doxastic justification. This much is obvious and unproblematic. Can evidential defeat destroy propositional justification as well? It is obvious neither that it can nor that it cannot. ${ }^{3}$

\footnotetext{
${ }^{3}$ Consider Pollock's definition of a defeater: "If $\mathrm{P}$ is a reason for $\mathrm{S}$ to believe $\mathrm{Q}, \mathrm{R}$ is a defeater for this reason if and only if $\mathrm{R}$ is logically consistent with $\mathrm{P}$ and (P\&R) is not a reason for S to believe Q.” Pollock 1986, p. 38. According to this definition, R's being a defeater entails that the conjunction of $\mathrm{P}$ and $\mathrm{R}$ fails to be a reason for $\mathrm{S}$ to believe Q. This leaves open whether P by itself continues to be a reason for S to believe Q. However, on p. 40 in Pollock 1974, we find the following passage: "An inductive reason for accepting a generalization can be defeated on at least two grounds. First, no matter how strong the initial inductive evidence for the generalization, if further investigation reveals a counterexample then the original reason ceases to be a good reason. Second, if it is discovered that the sample on which the original generalization was based was not a fair sample, this will make the initial reason no longer a good reason even though it was a good reason until this was discovered."
} 
The example of the red-looking table raises the question of whether undermining defeaters can destroy propositional justification. There are also examples that raise the question of whether rebutting defeaters can destroy propositional justification. Suppose you are in charge of a murder investigation. In the murdered person's apartment, two sets of finger prints (in addition to the victim's own) are found. The first set is identified as belonging to Jones, the second as belonging to Smith. So you have some evidence pointing to Smith as the murderer, and some evidence pointing to Jones as the murderer. Upon further investigation, it turns out that Jones was killed in a car accident several days before the murder. This discovery is a rebutting defeater for Jones' fingerprints as justification for believing that Jones is the murderer. How should we describe your epistemic situation? Should we say that Jones' fingerprints continue to give you stc, but fail to give you atc, justification for believing that Jones is the murderer? Or should we say that Joe's fingerprints no longer give you even stc justification for believing that Jones is the murderer? If we say the former, we view the propositional justification coming from your knowledge of the Jones's fingerprints as merely rebutted but not destroyed. If we say the latter, we view it as both rebutted and destroyed.

The question of whether evidential defeat can be destructive assumes fundamental significance when we consider three main theories of perceptual justification: dogmatism, conservatism, and meta-evidentialism. According to dogmatism, a sense experience is always a source of justification. According to conservatism, a sense experience is a source of justification unless evidence of unreliability destroys its justificational force. According to meta-evidentialism, a sense experience is not a source of justification unless evidence of reliability confers justificational force on it. Dogmatism denies that evidential defeat can be destructive. Conservatism and meta-evidentialism agree that it can. But they disagree on when a sense experience's justificational force is destroyed. According to conservatism, the lack of reliability evidence does not destroy it; only evidence of unreliability does. According to meta-evidentialism, the justificational force of a sense experience can be destroyed in both of these ways. Next, we will consider each of these views in greater detail.

[My italics.] If we assume that a good reason is a source of justification and a bad reason is not, then this passage clearly suggests that defeated reasons no longer have justificational force. 


\section{Dogmatism}

Theories of perceptual justification are either externalist, internalist, or hybrid combinations of both approaches. ${ }^{4}$ The three theories mentioned above are of the non-hybrid internalist variety. Neither of them takes de facto reliability to be neither necessary or sufficient for a sense experience to have justificational force. The first of them, dogmatism, is sometimes attributed to H. H. Price, G. E. Moore, and Roderick Chisholm. ${ }^{5}$ More recently, Michael Huemer and James Pryor have defended this view. Labeling it 'phenomenal conservatism', Huemer articulates it as follows:

If it seems to $S$ as if $P$, then $S$ thereby has at least prima facie justification for believing that $P{ }^{6}$

Pryor refers to the view as 'dogmatism' and states it thus:

My view is that whenever you have an experience as of $p$, you thereby have immediate prima facie justification for believing $p^{7}$

Since I will reserve the label 'conservatism' to refer to a theory that is opposed to dogmatism, I will use Pryor's label. As the passages I just cited make abundantly clear, dogmatism comes with two essential components. Here is the first:

Sufficiency: Having a sense experience as of $p$ is sufficient for having defeasible justification for $p .^{8}$

The second component, explicitly expressed in Pryor's passage, concerns the nature of the justification for which a sense experience as of $p$ is sufficient:

Immediacy: The justification a sense experience provides for believing its content is immediate.

A sense experience provides immediate justification for believing $p$ if, and only if, its justification force does not rest on, or come from, justification for believing any further proposition. For example, it might be held that, when you have justification for believing that the table before is red because it looks red to you, the justification coming from your

\footnotetext{
${ }^{4}$ For an example of a hybrid theory of perceptual justification, see Brogaard 2013.

5 See Alston 1999, p. 235.

${ }^{6}$ Huemer 2001, p. 99.

7 Pryor 2000.

${ }^{8}$ Here are two passages that define dogmatism in terms of Sufficiency. The first is by Elia Zardini: "Dogmatism about perceptual justification holds ... that one's having a (perceptual) experience as though $P$ suffices to provide one with an at least prima facie justification for believing that P." Zardini 2014, p. 35. The second is by Chris Tucker: "Necessarily, if it seems to $\mathrm{S}$ that $\mathrm{P}$, then $\mathrm{S}$ thereby has prima facie (non-inferential) justification for P." Tucker 2010, p. 529.
} 
visual experience rests on additional justification you have, namely on justification for believing that there are no red lights shining at the table. If that were the case, your visual justification for believing that the table is red would be mediate. If, however, the table's looking red by itself gives you justification for believing that the table is red, without any help coming from additional justification for rejecting any local or global skeptical alternatives, then your visual experience gives you immediate justification for believing that the table is red.

Sufficiency entails Immediacy. Suppose we hold the following: a sense experience as of $p$ (SEp) provides justification for believing $p$ if and only if one also has justification for rejecting a defeater $d$. In that case, SE $p$ does not by itself provide justification for believing $p$, and thus is not sufficient for having justification for believing p. Rather, given our supposition, what is sufficient for having justification for believing $p$ is $\operatorname{SE} p$ plus having justification for rejecting $d$. Put the other way around, to say that $\mathrm{SE} p$ is sufficient for having justification for believing $p$ is to say that nothing else-such as justification for rejecting $d-$ is required for having justification for believing $p$. Hence, if having a sense experience is sufficient for having justification for believing its content, then the justification one has by virtue of having that experience is immediate.

Immediacy does not (as I will argue below) entail Sufficiency. We might therefore wonder whether we should view Sufficiency as an essential ingredient of dogmatism. I claim that we should, for two reasons. First, rejecting Sufficiency results in a theory that is significantly altered and should therefore be classified as distinct from dogmatism. Second, Huemer and Pryor are explicit about endorsing Sufficiency. Dogmatism, then, is the conjunction of Sufficiency and Immediacy. The view tells us that sense experiences are a source of immediate justification in all possible situations. It may therefore be stated thus:

Dogmatism: Sense experience is always a source of justification. As mentioned above, dogmatism is an internalist theory. The view implies that, if you are a brain in a vat, your sense experiences are a source of justification for you although they are completely unreliable. So unrecognized de facto unreliability does not defeat the justification coming from sense experiences. Furthermore, by virtue of asserting Sufficiency, dogmatism implies that neither evidence of unreliability nor the absence of evidence of reliability can destroy the justificational force of sense experiences. Epistemologists who find the latter point problematic must choose between conservatism and meta-evidentialism. 


\section{Conservatism about sense experience}

To identify and explain the dialectical context in which dogmatism and its two competitors, conservatism and meta-evidentialism, are situated, I will briefly shift my focus from propositional to doxastic justification. When we ask,

Q1 When is a perceptual experience a source of justification? our question is about propositional justification. But when we ask,

Q2 When does a perceptual experience succeed in justifying a perceptual belief? our focus is on doxastic justification. One influential answer to Q2 is commonly referred to as epistemic conservatism. ${ }^{9}$ According to this answer, being justified is a belief's epistemic default status. A belief is innocent unless guilty-justified unless one has evidence that the belief is false. So, conservatism about perceptual beliefs answers Q2 as follows: a perceptual belief is justified unless one has evidence that the belief is false.

Applying the innocent-until-proven-guilty principle to the first question, conservatism about sense experience answers Q1 in an analogous fashion: a subject's sense experience is a source of justification unless the subject has evidence that the experience is unreliable. According to this view (henceforth conservatism $\mathrm{SE}_{\mathrm{SE}}$ ), being a source of justification is a sense experience's default status. Sense experiences are innocent unless proven guilty-they are source of justification unless their justificational force is destroyed by evidence of unreliability. Against dogmatism, conservatism $\mathrm{SE}$ asserts that sense experience is not always a source of justification. Rather, sense experience has justificational force only as long as evidence of unreliability is absent. The view may therefore be stated thus:

ConservatismsE: Sense experience is a source of justification only if evidence of unreliability if absent. ${ }^{10}$

\footnotetext{
9 See Foley 1983 and Fumerton 2007.

10 The difference between dogmatism and conservatismse is subtle and not always fully appreciated. For example, Huemer's phenomenal conservatism asserts that a seeming as if $p$ is sufficient for having defeasible justification for believing $p$. If we are strict about identifying conservatism with a theory that treats justificational force as a defeasible (i.e. not indestructible) default status, then Huemer's view is an instance of dogmatism, not conservatism. Or consider the following characterization of dogmatism by Tucker: "If it perceptually seems to $\mathrm{S}$ that $\mathrm{P}$, then, in the absence of defeaters, $\mathrm{S}$ thereby has justification to believe P." (Tucker 2013, p. 2.) Although Tucker means to define dogmatism, what his definition expresses is conservatismsE. According to the view Tucker defines, justificational force is conditional upon the absence of defeaters. If defeaters are present, $\mathrm{S}$ does not have justification for believing that $\mathrm{P}$. This is conservatismsE, not dogmatism. It is crucial, then, to distinguish between (A) if $\mathrm{S}$ has an experience as of $p$, then $\mathrm{S}$ has defeasible justification for believing $p$, and (B) if $\mathrm{S}$ has an experience as of $p$ and (destructive) defeaters are absent, then $S$
} 
Unlike dogmatism, conservatism $\mathrm{SE}$ makes evidence of unreliability relevant to the question of whether a particular sense experience has justificational force. If you have a sense experience as of $p$, and you have evidence that this experience is unreliable, then, conservatism $\mathrm{SE}_{\mathrm{E}}$ says, this experience is not a source of justification for you. It emits no justificational juice at all. ${ }^{11}$ Epistemologists who think that evidence of unreliability can block a sense experience from having justificational force will consider conservatism ${ }_{\mathrm{SE}}$ more plausible than dogmatism. However, some epistemologists will consider conservatismse problematic because the view agrees with dogmatism that evidence of reliability is irrelevant. According to both dogmatism and conservatism $\mathrm{SE}$, a sense experience's justificational force does not require or rest on evidence of reliability. A particular sense experience is a source of justification for you even if you have no evidence whatever in support of its reliability. Epistemologists who think that evidence of reliability is necessary must reject both dogmatism and conservatism $\mathrm{SE}$.

Unfortunately, in the current literature, the term 'conservatism' is used in two different and opposing ways. Initially, the term was used to refer to the view that beliefs are innocent unless proven guilty, that is, justified unless undermined or rebutted by defeaters. In his 2001 book Skepticism and the Veil of Perception, Huemer adopted the label for his preferred view of perceptual justification: phenomenal conservatism. Around the same time, Pryor chose the term 'dogmatism' as the name for the theory of perceptual justification he defended in his 2000 article "The Skeptic and the Dogmatist". Although there are differences in the way Huemer and Pryor articulate their respective views, they are essentially alike. However, and perhaps unfortunately, in his 2004 article “What's Wrong With Moore’s Argument?”, Pryor coined the distinction between liberal and conservative treatments of hypotheses and thereby spurred a use of the term 'conservative' on which Huemer's phenomenal conservatism is to

has justification for believing $p$ that is defeasible via undermining or rebutting. (A) is dogmatism, (B) is conservatismsE.

11 Alston takes Chisholm to be a dogmatist about perceptual justification. (Alston 1999, p. 235). The view he ascribes to Chisholm is that perceptually taking there to be a tree is sufficient for having prima facie justification for believing there to be a tree. However, on p. 48 of Chisholm 1989, we find the following passage: "The assumption is that, occasionally at least, the senses provide us with evidence pertaining to the existence of such things as trees, ships, and houses. The best answer to the question, "What is the nature this evidence?" seems to be this: the fact that we are appeared to in certain ways tends to make it evident that there is an external thing that is appearing to us in those ways. And the fact that we take there to be a tree tends to make it evident for us that there is a tree that we perceive." (Italics by Chisholm.) Two points deserve emphasis: First, Chisholm asserts that the senses give us evidence only occasionally. Second, he emphasizes that the senses merely tend to give us evidence about external objects. This suggests Chisholm might have agreed that the senses do not always give us evidence. He might actually have been a conservative rather than a dogmatist about perceptual experiences as a source of justification. 
be classified as a non-conservative view. Briefly, Pryor's distinction goes as follows. If we treat local or global error possibilities for believing $p$ conservatively, then we hold that a sense experience as of $p$ provides justification for believing $p$ only by virtue of additional justification for rejecting such defeaters. Put differently, we then hold that a sense experience as of $p$ does not provide immediate justification. If, on the other hand, we treat local or global error possibilities for $p$ liberally, then we hold that a sense experience as of $p$ by itself, without depending on any help coming from justification for rejecting error possibilities, can

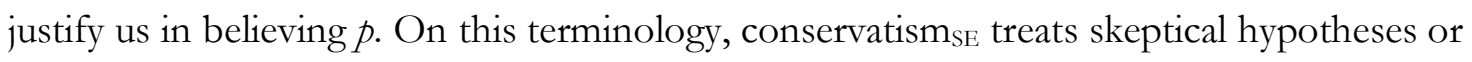
error possibilities liberally and thus turns into an instance of non-conservatism.

Here, I use the term 'conservative' to refer to the view that treats being a source of justification as a conditional default status: sense experiences possess that status unless a defeater destroys their justificational force. Readers must bear in mind, therefore, that conservatism in Pryor's sense of the term (and indeed what is referred to as 'conservatism' in much of the recent literature) is not the view I have labeled 'conservatism SE. $^{12}$ Next, I will discuss the second competitor for dogmatism.

\section{Meta-evidentialism}

To move on to the next step of the dialectic, let us consider again belief conservatism. Opponents of belief conservatism hold that the absence of evidence pointing to falsehood is not sufficient for a belief that $p$ to be justified. They hold that, for you to be justified in believing $p$, your total evidence must support believing $p$ by making $p$ probable. If such evidence is not in your possession, you must, assuming you don't have evidence for $\sim p$, suspend judgment. Consider Richard Feldman's counterexample to belief conservatism. ${ }^{13}$ Detective Jones has zeroed in on two suspects. She has good evidence that Lefty has committed the crime under investigation, and equally strong evidence that Righty has committed this crime. Suppose Jones finds herself, at the outset, believing that Lefty is the guilty culprit. Since her total evidence does not support the negation of the belief that Lefty committed the crime, belief conservatism tells us that her belief is justified. Feldman takes

\footnotetext{
12 In Tucker's 2013 collection Seemings and Justification, 'conservatism' typically refers to the dogmatic view Huemer and Pryor have defended. In contrast, in the collection Sceptism \& Perceptual Justification, (Dodd and Zardini 2014), the term 'conservatism' refers to views opposed to dogmatism. For an influential version of the latter type of conservatism, see Wright 2004 and 2014.

13 See Feldman 2003, p. 144.
} 
this to be the wrong outcome. For Jones, Feldman would say, the appropriate attitude is not belief but suspension of judgment.

Feldman is, of course, well known as an advocate of evidentialism. Why, as an evidentialist, does he reject belief conservatism? Belief conservatism is not, after all, an entirely non-evidentialist theory. According to it, negative evidence-evidence against a proposition's truth-is relevant. Such evidence renders beliefs unjustified. However, belief conservatism declares that positive evidence-evidence for a proposition's truth-is not necessary for a belief to be justified. To a strict evidentialist like Feldman, this is a fatal flaw. If one holds, as Feldman does, that negative and positive evidence are both determining factors of a belief's justificational status, then belief conservatism must be rejected.

Let us apply this thought to sense experience as a source of justification. According to Feldman's evidentialism, belief conservatism must be rejected because for a belief to be justified, the absence of negative evidence against it is not enough. Positive evidence in support of its truth is necessary. According to meta-evidentialism, conservatism $S_{S E}$ must be rejected because for a sense experience to have justificational force, the absence of evidence of evidence of unreliability is not enough. Positive evidence of reliability is necessary. The view may be stated thus:

Meta-Evidentialism: A subject's sense experience is a source of justification if and only if the subject has evidence of its reliability. ${ }^{14}$

This view is related to the kind of coherentism associated with Laurence BonJour and Keith Lehrer. ${ }^{15}$ However, there is a crucial difference between BonJour-Lehrer-style coherentism on the one hand and meta-evidentialism on the other. According to the former, what perceptual justification requires is coherence among first-order perceptual beliefs and metabeliefs about the circumstances under which the first-order belief formed. According to the latter, what perceptual justification requires is not coherence between actual first-order and second-order beliefs, but rather coherence between perceptual experiences and evidence for potential meta-beliefs about the experience's reliability. Since I wish to avoid the impression

\footnotetext{
${ }^{14}$ Two points of clarification: First, I'm going to use the phrase 'has evidence of $x^{\prime}$ s reliability' as a short for saying 'has a body of evidence that in its totality justifies the ascription of reliability to $x$ '. Reference to the subject's total evidence is necessary because defeated evidence of reliability does nothing towards making a perceptual experience a source of justification. Second, like conservatism, meta-evidentialism requires the absence of evidence of unreliability. This is to be understood as the condition that the subject's experience is not unreliable in light of the subject's total evidence. Since having a body of evidence that in its totality justifies the ascription of reliability entails this condition, it need not be stated separately.

${ }^{15}$ See BonJour 1985 and Lehrer 1990.
} 
that meta-evidential is an instance BonJour-Lehrer-style coherentism, I will not to use the label 'coherentism' for the third view I discuss in this paper. ${ }^{16}$

SE-conservatives and meta-evidentialists are united in rejecting dogmatism because, if dogmatism were true, evidence of unreliability would be irrelevant to the question of whether a sense experience is a source of justification. But they disagree about the relevance of evidence of reliability. Meta-evidentialists take evidence of reliability to be a necessary condition. SE-conservatives deny that it is since they consider the absence of evidence of unreliability to be sufficient.

\section{Justificational force and reliability evidence}

The table below sums up the differences between dogmatism, conservatism ${ }_{\mathrm{SE}}$, and metaevidentialism. ' $\mathrm{E}$ ' stands for evidence strong enough for knowledge. 'E(R)' stands for 'having knowledge-strength evidence of reliability', ‘ $\sim \mathrm{E}(\mathrm{R})$ ' stands for 'not having knowledgestrength evidence of reliability', and ' $\mathrm{E}(\sim \mathrm{R})$ ' means 'having knowledge-strength evidence of unreliability'. The box stands for 'is necessary for perceptual justification.' To say that $\mathrm{E}(\mathrm{R})$ is necessary for perceptual justification is intended to mean that the justificatory power of a particular sense experience depends on and comes from additional justification for ascribing reliability to that experience. Finally, 'D' stands for 'is a destructive defeater'. The knowledge-strength requirement on evidence is needed because I do not wish to burden conservatism $_{\mathrm{SE}}$ with the claim that very weak evidence of unreliability is sufficient for destroying the justificational force of a sense experience. ${ }^{17}$

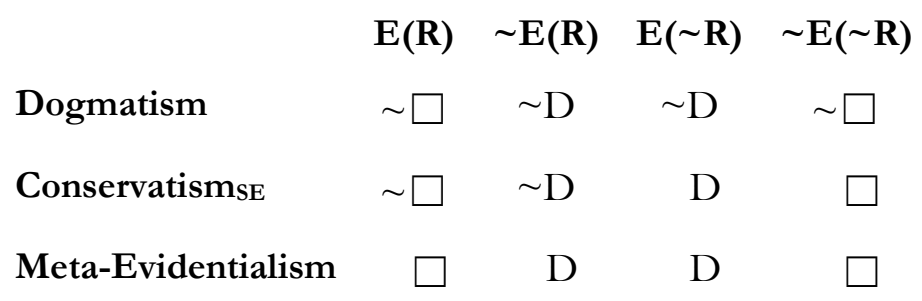

According to dogmatism, the justificatory power of a particular sense experience depends neither on the presence of reliability evidence nor on the absence of evidence of unreliability.

\footnotetext{
16 Moreover, since meta-evidentialism allows for a perceptual belief to be basic in the sense that it can be justified without receiving support from any beliefs, meta-evidentialism qualifies as a version of foundationalism. At the same time, though, since meta-evidentialism makes immediate justification impossible, there is also a sense in which the view qualifies as a (non-doxastic) version of coherentism.

17 Given these stipulations, the following is possible: although you have a little bit of evidence that your sense experience as of $p$ is unreliable, your experience nevertheless gives you stc justification for believing $\mathrm{p}$.
} 
Neither the former nor the latter destroys the justificatory power of the experience. According to meta-evidentialism, a particular sense experience's justificatory power comes from evidence that gives the subject justification for viewing the experience as reliable. The experience's justificatory power is destroyed not only if the subject's total evidence indicates unreliability, but also if it fails to certify that the experience is reliable. Conservatism $\mathrm{SE}$ occupies a middle ground between dogmatism and meta-evidentialism. Conservatism $\mathrm{SE}$ agrees with dogmatism that reliability evidence is not necessary for perceptual experiences to generate justification. However, conservatism $\mathrm{SE}_{\mathrm{E}}$ agrees with meta-evidentialism that justificational force requires the absence of evidence of unreliability. Having such evidence, according to conservatism $\mathrm{SE}$, destroys a sense experience's justificatory power.

The three theories I have introduced raise two important questions. The first concerns the conservative rejection of dogmatism: Why think that evidence of unreliability can destroy perceptual justification? The second question concerns the meta-evidentialist rejection of conservatism $_{\mathrm{SE}}$ : Why think that the absence of evidence of reliability can destroy perceptual justification? In the next section, I will address the first of these questions. The second will be discussed further below. In the remainder of this section, I will make two more points about justificational force.

First, according to dogmatism, sense experience is always a source of justification. There are three non-dogmatic theories that reject this claim.

Conservatism $\mathrm{SE}_{\mathrm{E}}$ : Sense experience fails to be a source of justification when there is evidence of its unreliability.

Meta-evidentialism: Sense experience also fails to be a source of justification when there is no evidence of its reliability.

Skepticism: $\quad$ Sense experience is never a source of justification. Huemer and Pryor's anti-skeptical dogmatism is at one end of the spectrum, skepticism at the other end. Nested in between are conservatism $\mathrm{SE}$ and meta-evidentialism as the two nondogmatic alternatives.

Second, according to conservatism ${ }_{\mathrm{SE}}$, sense experience is innocent unless proven guilty. On this approach, to say that a sense experience is innocent is to say that it is a source of justification (that it has justificational force). Put differently, conservatism $\mathrm{SE}_{\mathrm{E}}$ takes justificational force to be a defeasible default status. There are two non-conservative theories that reject this claim. 
Dogmatism

Meta-evidentialism:
Sense experience is always innocent. Its justificatory power cannot be destroyed. It continues to have justificational force even if there is evidence of unreliability.

The default status of sense experience is that of being guilty unless proven innocent. A sense experience has justificational force only if there is evidence of its reliability.

According to conservatism $\mathrm{SE}_{\mathrm{E}}$, a sense-experience can fail to be innocent. If there is sufficiently strong evidence of unreliability, a sense experience fails to have justificational force. Dogmatism is a non-conservative view because it denies this possibility. In contrast, meta-evidentialism is a non-conservative theory because it replaces the default status of justificational innocence with that of justificational guilt. Now, how is meta-evidentialism related to skepticism? If construed without an anti-skeptical amendment, meta-evidentialism allows for, and arguably even motivates, the following kind of skepticism.

Skepticism: $\quad$ Sense experience is never innocent. It never has justificational force because evidence-of-reliability is required for justificational force but does not exist.

We must, therefore, distinguish between skeptical and non-skeptical meta-evidentialism. The meta-evidentialist non-skeptic argues that justificational force requires evidence of reliability but holds that such evidence is available. The meta-evidentialist skeptic agrees that justificational force requires evidence of reliability but holds that such evidence cannot be found.

\section{Sufficiency and immediacy}

We are now in a position to see that, although Sufficiency entails Immediacy, Immediacy does not entail Sufficiency. Suppose there is a table before you that looks red. You have no evidence of any kind suggesting that, under the present conditions, your visual experience is misleading. Both dogmatism and conservatism $\mathrm{SE}_{\mathrm{SE}}$ tell us that, in this situation, your experience gives you justification for believing that the table is red. And, like dogmatism, conservatism $\mathrm{SE}$ denies that the justificational force of your experience partially comes from any additional justification you might have for rejecting local or global skeptical hypotheses. Rather, on both views, your visual experience by itself justifies you in believing that the table is red. So on both views, your experience provides immediate justification for believing its content. So 
Immediacy does not require Sufficiency. It is not the case that, for a sense experience to provide immediate justification, it must always have justificational force. Immediacy can be had without, and thus does not entail, Sufficiency.

Given that conservatism $\mathrm{SE}_{\mathrm{SE}}$ rejects dogmatism but allows for immediate justification, we may wonder what motivation there is for preferring dogmatism to conservatism $\mathrm{SE}$, particularly since the claim that sense experience is a source of justification no matter what is, on the face of it, quite implausible. To the eyes of its advocates, what recommends dogmatism is its anti-skeptical force. Compare dogmatism with meta-evidentialism, according to which justificational force requires evidence of reliability. This requirement is grist on the skeptic's mill. Rejecting it-arguing that perceptual justification can be immediate_-goes a long way towards keeping skepticism at bay. However, as I just argued, dogmatism is not the only theory according to which perceptual justification can be immediate. Conservatism $\mathrm{SE}$ also allows for Immediacy and therefore has no less antiskeptical force than dogmatism does. It therefore is a bit of a mystery to me why dogmatists, inasmuch as they aim to secure the result that perceptual justification can be immediate, go as far as committing themselves to Sufficiency. In light of the problem cases I will discuss next, it seems to me dogmatists would be well advised to retreat to the weaker position of advocating conservatism ${ }_{\mathrm{SE}}{ }^{18}$

\section{Problem cases for dogmatism}

The debate over dogmatic versus non-dogmatic theories of perceptual justification raises the question of whether evidential defeat can destroy justificational force. Beginning with this section, I will proceed to argue that it can. Eventually I will argue that, of the three theories we have considered, meta-evidentialism in the most plausible. In this section, I will describe four cases that support favoring conservatism $\mathrm{SE}$ over dogmatism.

\footnotetext{
${ }^{18}$ Huemer and Pryor say things suggesting that they might actually not be opposed to conservatismsE. For example, on p. 100 in his 2001, Huemer explicitly endorses the spirit of conservatism. This suggests to me he might actually accept that a perceptual experience is a source of justification unless one has reason to think otherwise. On p. 354 of his 2004, Pryor suggests that, according to a liberal treatment of a visual experiences of your car, for such experiences to give you justification for believing your car is present, "it's enough that you lack reason to believe your experiences are unreliable." If that's liberalism, then liberalism is to be identified with not dogmatism but conservatism $\mathrm{SE}$ instead. Finally, on p. 96 in his 2013, Pryor says: "When I began several years ago to use the term dogmatism, I meant the view that . . justification is sometimes both immediate and underminable." In this passage, Pryor identifies dogmatism with the view that defeasible justification can be immediate. Thus understood, dogmatism is not committed to Sufficiency and therefore consistent with conservatismsE.
} 
1. Gold prospectors. Peter Markie has described a case involving two gold diggers, Gus and Virgil. ${ }^{19}$ Gus is an expert, Virgil a novice. Looking at a yellow looking pebble, it seems to each of them that they have found a gold nugget. To Gus, it seems the pebble is gold because, as an experienced prospector, he recognizes gold when he sees it. To Virgil, it seems the pebble is gold not on the basis of expertise but because he is influenced by his desire to find gold. Dogmatists and advocates of conservatism ${ }_{S E}$ agree that, whereas Gus is justified in believing that the pebble is gold, Virgil is not. Virgil is not justified in believing this because, knowing he is an inexperienced novice, he has a defeater: he knows he is a novice and thus unreliable in discriminating between actual gold nuggets and pebbles that merely look like gold. ${ }^{20}$ Dogmatists and advocates of conservatism ${ }_{S E}$ disagree on whether Virgil's visual experience — the pebble's looking gold-like-is a source of justification for him. Dogmatists say that his visual experience has justificational force, SE-conservatives say that it does not.

2. The Müller-Lyer illusion. In the diagram below, line 3 seems shorter than line 4. Call this the unequal length appearance. At the same time, lines 1 and 2 seem to be of the same length. Call this the equal length appearance. Finally, the two parallel vertical guidelines make it entirely clear that all four lines are of the same length. They make it obvious that, whereas the equal length appearance corresponds to reality, the unequal length appearance is not merely unreliable but in fact a misleading visual illusion.

\footnotetext{
${ }_{19}$ See Markie 2013, p. 257. The case is meant to be a counterexample to Huemer's phenomenal conservatism. For Huemer's reply, see Huemer 2013, p. $343 \mathrm{f}$.

20 In describing the case as involving a defeater, I deviate from the way Markie construes the case. According to Markie, if defeaters are taken to be mental states, it remains unclear whether Virgil has a defeater. See Markie 2013 , p. 258. We could of course imagine Virgil to be suffering from the delusion of being expert, where this delusion is realistic enough to justify him in this belief. Huemer replies (correctly, I think) that, if interpreted in such a way, the case does not challenge phenomenal conservatism (or, for that matter, dogmatism), just as BIV scenarios do not. For the case to be an effective problem case for phenomenal conservatism, we must image Virgil to have a defeater. If we imagine him to be an unreliable novice, it is hard to see how he can fail to have a defeater. And if we imagine him to be aware of his strong desire to find gold, then he would have a second defeater.
} 


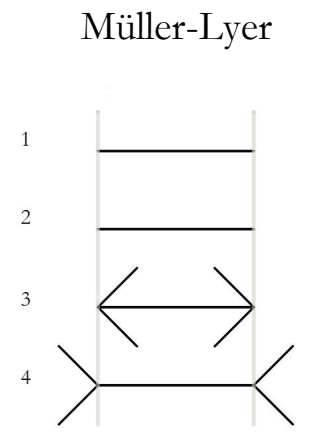

According to dogmatism, the equal length appearance gives you justification for believing that lines 1 and 2 are of equal length, and the unequal length appearance gives you justification for believing that line 3 is shorter than line 4 (or alternatively that line 4 is longer than line 3). Noticing the vertical guidelines, dogmatism says, defeats the different length appearance, not by destroying it as source of justification, but by merely undermining it. Even though it is undermined, it continues to have justificatory force. But since it is undermined, doxastic justification is blocked. If you were to believe that line 3 is shorter than line 4 , your belief would not be justified. Conservatism ${ }_{S E}$, on the other hand, says that the different length appearance is not a source of justification. Its justificatory power is destroyed.

3. The hallucinated oasis. Crossing a desert, you suffer from too much heat, not enough sleep, too little water, and general exhaustion. Near the end of a day of unrelenting heat, it looks to you as though there is a cluster of palm trees nearby. Your fellow travelers assure you that they don't see what you seem to be seeing. You know that, under the present conditions, one easily hallucinates an oasis. This is an undermining defeater for you. You also know that your fellow travelers do not see any oasis. That is a rebutting defeater for you. Nevertheless, according to dogmatism, your visual palm tree experience gives you some justification for believing that there is an oasis nearby. According to conservatism $\mathrm{SE}_{\mathrm{SE}}$, it does not because have evidence, and indeed know, that your visual experience is unreliable. This destroys its justificational force.

4. The knowing BIV. Consider the modal ambition that's an essential aspect of dogmatism. According to dogmatism, having a sense experience as of $p$ is logically sufficient for having justification for believing that $p$ : in every possible situation in which there are cognitive beings capable of having sense experiences and forming beliefs on their basis, their 
sense experiences are a source of justification for them. In short, sense experience is necessarily a source of justification, a source of justification no matter what. That's a strong claim—-too strong to be plausible. To assess its plausibility, we may consider possible cases however unlikely and far-fetched they may be. So suppose you are a brain in a vat, but not the standard envatted brain having the experience of a normal life, but instead the nonstandard envatted brain that has acquired knowledge of its lamentable fate. ${ }^{21}$ Knowing you are envatted, are your artificially induced sense experiences still a source of justification for you? According to dogmatism, they are. Conservatism $\mathrm{SE}_{\mathrm{E}}$ tells us that that they are not.

I am inclined to judge that, in each of these cases, the justificational force of the perceptual experience in question is destroyed. So I consider the conservative verdict about each of these five cases to be more plausible than the dogmatic verdict. Nevertheless, I do not think these cases, by themselves, conclusively support preferring conservatism $\mathrm{SE}_{\mathrm{E}}$ to dogmatism. I can see epistemologists sympathetic to dogmatism stick to their guns and claim that, in each of these cases, the perceptual experience in question continues to have at least some justificational force. However, I think it is fair to say that these cases succeed in raising significant doubt about dogmatism. In the next section, I will offer additional considerations that strengthen the conservative case against dogmatism.

\section{The conservative case against dogmatism}

According to dogmatism, our perceptual experiences are a source of justification no matter what. It is noteworthy that that is not our attitude towards witnesses and testimony. We do not think that someone's saying $p$ gives us always justification for believing $p$. When witnesses or pieces of testimony are discredited, we don't view them as a source of justification. A witness or a piece of testimony can be discredited in two ways: by an undermining and by a rebutting defeater. Consider the following case:

Witness Joe: Suppose you are a detective investigating a killing for which a member of a criminal gang is the main suspect. Gang member Joe provides an alibi. Not only do you know from previous encounters with him that Joe is sociopathic liar, you also know that Joe knows that, if he values his life, he had better provide the suspect with

\footnotetext{
${ }^{21}$ How might you acquire knowledge of being envatted? Imagine, for example, that on occasion you are having perceptual experiences completely incongruous with those you have most of the time. In these experiences, while feeling strangely disembodied and helpless, you see a large lab with technicians in white coats attending to multiple brains floating in their individual vats.
} 
an alibi. Joe utters $p$, thereby placing the suspect at a location far away from the location where the killing occurred.

Since Joe's credibility as a witness is completely undermined, it would be odd to insist that Joe's uttering $p$ is a source of justification. ${ }^{22}$ Joe's credibility is undermined even more strongly if we add a rebutting defeater.

Witness Joe continued: Unbeknownst to Joe, there is CCTV footage clearly showing how the suspect commits the killing with an automatic pistol. So now you know not only that gang member Joe is an untrustworthy witness, you also know that, in uttering $p$, he is lying.

It would now be even odder to insist that Joe's uttering $p$ gives you justification for believing $p$. An analogous line of reasoning applies to instruments and gauges. Here is another case: Broken gas gange: Suppose you know that you car's gas gauge is broken. For several months, the needle has been stuck in the empty position. You could get it fixed for about $\$ 1,000$, but you don't want to spend the money. Suppose further you just filled up the tank. You credit card is charged for nearly 15 gallons of gas, and you get back behind the wheel. As you turn on the car, you notice that that needle of your gas gauge points to empty.

In this situation, you know that the needle position of your gas gauge is misleading. Put differently, you know your gauge is 'lying': it says the tank is empty when in fact it is full. Does the needle's position give you any justification to believe that the tank is actually empty? I feel no hesitation to say it does not.

Dogmatism about witnesses, testimony, instruments, and gauges says that they are a source of justification no matter what. According to the conservative position on this matter, they are a source of justification as long as they are not discredited. The two examples we considered, it seems to me, make the conservative position more plausible than the dogmatic position. But then there is reason to think that conservatism $\mathrm{SE}_{\mathrm{E}}$ is more plausible than dogmatism about perceptual experiences. Here is why.

Suppose the dogmatist about perceptual experiences also endorses dogmatism about witnesses, testimony, instruments, and gauges. This would be a rather uncomfortable position, exacting the hefty cost of having to say, for example, that an utterly discredited

22 As an anonymous referee suggested, it might be objected that Joe's testimony provides at least some tiny bit of justification for believing $p$ because, given Joe's assertion, it is now just a tiny bit more probable that $p$ is true. I discuss this type of objection in the next section. 
witness remains a source of justification. Alternatively, suppose the dogmatist about perceptual experiences endorses conservatism about witness, testimony, instruments, and gauges. This would be an unprincipled and unstable position. For we may reasonably wonder why it should be that, whereas witnesses, testimony, instruments, and gauges can cease to be source of justification by virtue of being discredited, perceptual experiences cannot. Consider again the Müller-Lyer illusion. You know that the unequal length appearance is unreliable, and you know that, in the case at hand, it is misleading. So why would it be that, when you know about a witness that he is both unreliable and lying, the witness ceases to be a source of justification, but when you know about a perceptual experience that it is unreliable and misleading, it continues to be a source of justification? It seems arbitrary and indefensible to use one standard for witnesses, testimony, instruments and gauges, and another, easier standard for perceptual experiences. If, with regard to perceptual experiences, dogmatism is replaced with conservatism $\mathrm{SE}_{\mathrm{SE}}$, one standard is consistently applied in both areas. In conclude that, when we consider perceptual experiences in the larger context of also considering witnesses, testimony, instruments, and gauges, conservatism $\mathrm{SE}$ is more plausible than dogmatism. ${ }^{23}$

Advocates of dogmatism might reply to this objection that perceptual experience have a phenomenal force or assertiveness — a feel of being caused by external fact — that witnesses, instruments and gauges lack. ${ }^{24}$ Therefore, dogmatists have the resources to rebut the objection that their position is unprincipled. My response to this reply is twofold. First, it seems to me that hearing a witness, observing an instrument, and reading a gauge can come with the same degree of phenomenal force as clear and distinct perceptual experiences. Second, suppose you have a sense experience as of $p$ and, even though your experience is maximally clear and distinct, you know that it is hallucinatory. I fail to see why its

\footnotetext{
${ }^{23}$ An anonymous referee suggested that my argument here counts as well against meta-evidentialism. According to the referee, I claim it's arbitrary to endorse dogmatism about sense experience while rejecting dogmatism about witnesses and gauges. At the same time, the position I defend, meta-evidentialism, forces me to say it's not arbitrary to endorse self-support coming from sense experience and memory while rejecting selfsupport provided by witnesses and gauges. In reply, I deny that meta-evidentialism cannot allow for witnesses and gauges to provide self-support. When interviewing a witness and asking the right kind of questions in the right way, it is possible to acquire from the witness evidence supporting the witness's reliability. Likewise, it is possible for gauges to provide self-support. Think of a gas gauge equipped with a device to monitor its reliability, consisting of sophisticated sensors and electronics. This device monitors every way in which a gas gauge might fail in relevantly close scenarios. As long as the gas gauge functions reliably, a green light is on. In case of malfunction, the light turns red. Arguably, a sophisticated gauge like that provides its user with (epistemically valuable) self-support.

${ }^{24}$ This reply on behalf of dogmatism was suggested by an anonymous referee.
} 
phenomenal force should protect the experience from losing all of its justificatory force given you know it is hallucinatory and therefore completely misleading.

A second consideration in favor of conservatism has to do with the point of justification. We value justification because we take it to be a path to truth. ${ }^{25}$ We prefer having justified to having unjustified beliefs because we prefer having true beliefs to having false beliefs. This thought stands in the way of the dogmatic position that perceptual experiences are always a source of justification. According to conservatism $\mathrm{SE}$, a sense experience is not always a source of justification. It is not when we know that is not a path to truth. We might have knowledge of an undermining defeater. In that case, we know that the experience is unreliable. We might have knowledge of a rebutting defeater. In that case, we know that the experience is misleading. In either case, the experience fails to function as a source of justification precisely because we know it is not a path to truth. According to dogmatism, the experience continues to be a source of justification although we know it fails to be a path to truth. Once again, it seems to me, we are looking at a consideration that favors conservatism $\mathrm{SE}$ over dogmatism.

Dogmatists might respond that, on their view, the path-to-truth consideration is given its full due because they would agree that, in each of the problem cases I have described, the subject's belief is unjustified. The point of justification is, after all, that we end up with true rather than false beliefs. ${ }^{26} \mathrm{I}$ find this response unconvincing. It engenders a strange bifurcation between propositional and doxastic justification. Consider again the case of witness Joe. The proposal under consideration is the following:

(i) although you know that Joe is lying, Joe's assertion of $p$ gives you some justification for believing $p$,

(ii) but since you know that he is lying, you would not be justified in believing $p$ on the basis of Joe's testimony.

My response is that the path-to-truth consideration applies to both propositional and doxastic justification. Viewing Joe's assertion of $p$ as a source of justification although you know Joe is lying is odd. The view's oddness is not diminished by pointing out that, in the end, you wouldn't be justified if you were to believe $p$. Rather, the view's oddness persists because we expect sources of justification to point us in the direction of truth. A known lie

${ }^{25}$ For a clear articulation of the path-to-truth conception of justification, see BonJour 1985, p. 8f. See also what Alston says about the 'epistemic point of view': Alston 1989, p. $83 \mathrm{f}$.

${ }^{26}$ This reply on behalf of dogmatism was also suggested by an anonymous referee. 
doesn't point us in the direction of truth. That is why Joe's assertion of $p$ should not qualify as a source of justification. Analogous considerations apply to gauges we know to be broken and experiences we know to be hallucinatory.

The path-to-truth argument reinforces the four cases we considered in the previous section. To Virgil, it perceptually seems he is holding a gold nugget in his hands. But he knows he is an unreliable novice. In the Müller-Lyer case, line 3 seems shorter to you than line 4. But you know that the angle brackets create an illusion, and you know that lines 3 and 4 are in fact equally long. In the desert travel case, you know you are hallucinating. Finally, as a BIV who is aware of being envatted, you know your sense experiences are completely unreliable. In each case, you know that your experiences are not a path to truth. This reinforces the conservative judgment that the experiences in question lack justificational force.

\section{The never zero argument}

In response to the four problem cases for dogmatism, advocates of the view might deploy what I will call the Never Zero Argument. It rests on the premise that the evidential scales never rise all the way up to completely unopposed justification or decline all the way down to zero justification. Therefore, perceptual justification for $p$ is never completely unopposed, and doubt about $p$ is never completely lacking in justificational force. Let us apply this thought to each of the problem cases for dogmatism:

(i) In Markie's case of two gold prospectors, Virgil cannot be completely certain that, given his his inexperience and strong desire to find gold, he is being misled when the pebble looks like gold to him. Therefore, his visual experience is still a source of at least some justification for him.

(ii) In the Müller-Lyer illusion, the vertical guidelines and the equal length appearance are powerful evidence that lines 3 and 4 have the same length. But this evidence is not powerful enough to give you completely unopposed certainty that lines 3 and 4 have the same length. Perhaps the two vertical guide lines are not quite parallel. It might be that line 3 is actually slightly shorter than line 4 . Therefore, the unequal length appearance continues to be a source of justification. However, the degree of justification it generates is very small. 
(iii) In the desert travel case, you cannot be completely certain that you are hallucinating when you seem to be perceiving nearby palm trees. Therefore, your palm tree experience still gives you at least some justification that you are near an oasis.

(iv) Even if you know that you are a BIV, your justification for taking yourself to be a BIV does not rise to the level of absolute certainty. Things might merely seem to you that way because you are under the influence of a powerful hallucinogenic drug. Therefore, your perceptual experiences still give you at least some justification for your beliefs about your physical surroundings. According to the Never Zero Argument, for each of the five cases, it is not counter-intuitive to judge that the perceptual experience in question does not completely lose its justificational force. If the Never Zero Argument is sound, the four test cases do not refute dogmatism. For dogmatism doesn't say that, in each of the four cases, believing the proposition in question would be justified. Nor does dogmatism say that, in each of the four cases, the perceptual experience in question has undiminished justificational force. Dogmatism merely says that, in each of these cases, the justificatory force of the subject's perceptual experience is not completely destroyed. That claim is not implausible because, in each of the five cases, the subject's perceptual experience generates only an extremely low degree of justification.

The Never Zero Argument deserves serious consideration. It is quite plausible that, neglecting a few exceptions, the evidential scales never rise all the way up to give you certainty of $p$ and never decline all the way down to give you certainty that $\sim p$. Moreover, it is plausible that different pieces of evidence can conflict with each other in such a way that one has some justification for believing $p$ and some justification for believing $\sim p$. In criminal investigations, this happens frequently. Witness $A$ says he saw the suspect at the scene of the crime. Witness $B$ says he saw him at a restaurant 10 miles away. If both witnesses are credible, they continue to be sources of justification. The detective has justification for and against placing the suspect at the scene of the crime.

Nevertheless, I do not find the Never Zero Argument compelling. From the premise that complete certainty can hardly ever be attained, it does not follow that a witnesses whom we know to be lying is still a source of justification. Consider again the case of witness Joe. On CCTV coverage (with high definition and excellent lighting), you clearly see the suspect carry out the killing. So you know he is guilty. Hence, when Joe says the suspect was 
elsewhere at the time in question, you know Joe is lying. According to the Never Zero Argument, you cannot be completely certain that the suspect is the killer. After all, perhaps the killer on the CCTV tape happens to be a look-alike doppelgänger of the suspect. Therefore, Joe's testimony gives you at least some very small amount of justification for believing the suspect is not the killer.

The question at hand is: Under which conditions does Joe's testimony lose all justificational force? According to the Never Zero Argument, it does if, and only if, you are completely certain, that is, if have the maximum amount of justification for believing, that the suspect is the killer. But there is an alternative I find more plausible: Joe's testimony loses all justificational force if you know that the suspect is the killer. The proposition

You know that Joe's assertion of $p$ is a lie, but his assertion nevertheless gives you some justification to believe $p$

strikes me as highly implausible. It looks like, to use Keith DeRose's apt term, an abominable conjunction. ${ }^{27}$ It seems to me, therefore, that the Never Zero Argument makes it too hard for the credibility of a witness to be destroyed. For the credibility of a witness to be destroyed, the evidence undermining his trustworthiness need not rise to the level of complete certainty. Knowing that a witness is lying is enough to destroy his credibility.

An analogous story can be told about the case of the broken gas gauge. According to the Never Zero Argument, the gas gauge ceases to be a source of justification only if you are completely certain that the tank is full. But you can't be completely certain of that. Perhaps, right after you stopped at the pump, you fell asleep behind the wheel and merely dreamed that you filled up the tank. Therefore, the gas gauge still gives you a small amount of justification for believing the tank is empty. If we go this route, we must say the following:

You know the tank is full, but the needle's pointing to empty gives you some justification to believe the tank is empty.

This, too, strikes me as an abominable conjunction. I think we are better off steering away from such an outcome. To me, it seems more plausible to say instead that, since you know that the tank is full, the needle's pointing to empty gives you no justification at all to believe the tank is empty. ${ }^{28}$

\footnotetext{
${ }^{27}$ De Rose applied the term 'abominable conjunction' to statements such as 'I know I have hands but I don't know I'm not a BIV.” See his 1995.

28 An anonymous referee suggested that there are two ways to defend the Never Zero Argument. First, it might be argued that fallibilism mandates the Never Zero view. For if fallibilism is true, it's possible to know $p$ even
} 
I submit, therefore, that the Never Zero Argument gives us implausible results when we test it against cases in which witnesses and gauges are discredited. These results undermine its effectiveness as a defense of the dogmatic reading of the four problem cases. About each of these cases, the Never Zero Argument denies that perceptual justification is destroyed on the ground that the relevant defeaters are not certain. It seems to me it is more plausible to say that, in each of these cases, perceptual justification is destroyed because the relevant defeaters are known. Virgil knows he is an unreliable novice. Therefore, the pebble's looking like gold to Virgil is not a source of justification for him. When you look at the Müller-Lyer illusion, you know that lines 3 and 4 are of the same length. Therefore, the unequal length appearance has no justificational force to you. In the desert travel case, you know you are hallucinating. Therefore, your visual palm tree experience gives you no justification at all for believing you are near an oasis. Finally, if you know you are a BIV, you have knowledge of a defeater that both undermines and rebuts your perceptual experiences. As a result, the experience in question is in each case known not to be a path to truth and therefore loses all of its justificatory power. That, it seems to me, is what we should say about the four problem cases. I do not think, therefore, that the Never Zero defense of dogmatism succeeds. ${ }^{29}$

\section{The meta-evidentialist case against conservatism}

According to dogmatism, perceptual justification is always a source of justification. Its justificatory power cannot be destroyed. That's a strange view. If it is held consistently for all sources of justification, it amounts to the astonishing claim that a source of justification will continue to be a source of justification no matter how much evidence we acquire for thinking that it is unreliable, untrustworthy, or outright misleading. Conservatism $\mathrm{SE}_{\mathrm{E}}$ is more

though one has a little bit of evidence that $p$ is false. For example, I might know that $p$ even though a witness I know to be lying asserts $\sim p$. In response, I do not agree that fallibilism mandates the Never Zero view.

According to fallibilism, knowledge does not require truth-entailing evidence. Endorsing fallibilism in this sense is consistent with denying that, in the case in question, knowledge of $p$ comes together with some justification for believing $\sim p$. According to the second way of defending the Never Zero Argument, the assertions I claim are abominable are in fact true but not felicitously assertible because they generate false implicatures. But what might the false implicatures be? Unless a convincing story is told about which false implicatures the assertions in question generate, the true but unassertible maneuver remains implausible.

${ }^{29}$ The argument presented here suggests a way to identify when a defeater destroys perceptual justification and when a defeater merely undermines perceptual justification without destroying it. Whether a defeater destroys justificational force or merely undermines might depend on whether the defeater is known. For example, when you know that you are hallucinating, perceptual justification is destroyed. But when you have only weak evidence that you are hallucinating, evidence falling short of giving you knowledge, then the defeater does not destroy the justificational force of your experience but merely undermines it, thus preventing you from having all things considered justification. 
plausible than dogmatism because it denies that perceptual justification is always a source of justification. A perceptual experience fails to have justificational force if there is knowledge grade evidence of unreliability. But, we might wonder, if we expect justification to be a path to truth, is the absence of evidence of unreliability really enough to make a perceptual experience a source of justification? Why would it be, if truth is what we are after, that a perceptual experience is a source of justification even if we have no evidence of reliability, and thus have no reason to believe it is guiding us towards truth? It would seem that, if we take seriously the expectation that justification be truth conducive, meta-evidentialism should be preferred to conservatismsE.

Suppose you have a perceptual experience as of $p$. If your experience gives you justification for believing $p$, and if justification is a path to truth, then your total evidence must support viewing your experience as of $p$ as an indication that $p$ is true. When is this condition satisfied? Clearly not if your evidence indicts your experience as unreliable. But the absence of evidence of unreliability does not seem to be enough. It would seem that an experience as of $p$ is an indicator of $p$ 's truth only if your total evidence certifies your experience as reliable. Put differently, if we take the path-to-truth requirement seriously, we must hold that a particular sense experience's justificational force comes from justification for attributing reliability to it. On this view, sense experience owes its justificational force to evidence of its reliability (in addition to the absence of evidence of unreliability). If this line of reasoning is sound, meta-evidentialism must be preferred to conservatism $\mathrm{SE}_{\mathrm{E}}{ }^{30}$

30 An anonymous referee suggested that there is a Moorean response to this. It goes as follows. Both dogmatism and conservatismse allow for a cognitive structure that includes plenty of evidence of perceptual reliability. Both views deny that the justificational force of sense experience comes from such evidence. Instead, it has its sole origin immediately justified perceptual beliefs. Via inferences from such beliefs, evidence for perceptual reliability can be generated via inference. Therefore, both views are capable of satisfying the path-totruth requirement. I offer two brief replies. First, the proposed inference from immediately justified perceptual beliefs to justified belief in perceptual reliability runs into one of the main liabilities of both dogmatism and conservatism $\mathrm{SE}$ : the problem of easy knowledge, as highlighted in Cohen 2002. Second, if dogmatists and SEconservatives accept justification closure, they must hold, given awareness of the entailment from, say, hand possession to non-envatment, that justification for believing I'm not a BIV (non-envatment-J) is necessary for justification for believing I have hands (hands-J). The claim in question is that hands-J does not come from or rest on non-envatment-J although non-envatment-J is necessary for hands-J. According to this line of reasoning, there is a coming-from or resting-on relation over and above the necessity relation at work in justification-closure. It is unclear what this additional relation is supposed to be. Advocates of dogmatism or SE-conservatism need to tell a convincing story of why we should think that the following is true: non-envatment $J$ is necessary for hands-J but hands-J does not rest on or come from non-envatment-J. Without such a story, the claim is a verbal maneuver without a substantive core. On behalf of the claim, it might be suggested that, for example, blood-supply to the brain is necessary for justified belief but surely a beliefs justification doesn't come from blood that's circulated through the brain. The idea is that an analogous point can be made for Hands-J and non-envatment-J. Although the point about blood-supply to the brain is well taken, in this example we have a 
Above, I argued that our attitude towards witnesses, testimony, instruments, and gauges supports favoring conservatism $\mathrm{SE}$ over dogmatism. Let us see whether our attitude towards these things also supports favoring meta-evidentialism over conservatism $\mathrm{SE}_{\mathrm{SE}}$. Testimony that is discredited lacks justificational force. That's why dogmatism about witnesses and testimony must be rejected. What about testimony that is not properly credentialed as reliable? What is our attitude towards such testimony? Let us consider an example. Suppose you come across a book on a controversial topic. You have no information about either the publisher or the author that allows you to judge whether the book is a reliable source of information. You have evidence of neither reliability nor unreliability. On p. 16, the author asserts proposition $p$. Does this give you justification for believing $p$ ? It seems to me our general attitude towards printed materials is that it does not.

Next, let us consider a case involving a Geiger counter. Assume you are part of the clean-up crew at the Fukushima power plant. Wearing a protective suit and equipped with a Geiger counter to monitor radiation levels, you get to work in a contaminated area. Inside your helmet, there is a cell phone attachment allowing you to communicate with the control center. Having worked for a while, frequently using your Geiger counter to make sure radiation levels are within tolerable limits, you receive the message that your Geiger counter was taken from a storage cabinet with 5 reliable devices on one shelf and 5 malfunctioning devices on another shelf. Unfortunately, you are told, it is not known whether your Geiger counter was among the reliable or the malfunctioning devices. Now your epistemic situation is as follows: you have evidence neither for nor against the reliability of your Geiger counter. At present, the radiation levels are safe according to its needle position. The question is whether you still have justification for believing that the radiation levels are safe. It seems to me our general attitude towards instruments is that, since you have no longer any reason to consider your Geiger counter to be reliable, you do not.

Vis-à-vis conservatism $\mathrm{SE}$, dogmatism as a general approach to justificational force looks implausible when tested against cases involving discredited witnesses. Vis-à-vis metaevidentialism, conservatism about justificational force looks implausible when tested against cases involving witnesses and instruments without credentials of reliability. In response, advocates of the conservative approach have two choices. They can bite the bullet and say

contrast between an epistemic property and a non-epistemic condition, whereas when we consider hands- $J$ and non-envatment-J, we are looking at two different elements within an overall epistemic structure. I do not see, therefore, that pointing to non-epistemic necessity relations helps to render the claim in question plausible. 
that witnesses and instruments are sources of justification even if there is no evidence indicating that they are reliable and therefore trustworthy. This strikes me as a serious cost. Alternatively, they can apply one standard to witnesses and instruments and another one to perceptual experiences. They might say that, whereas witnesses and instruments are sources of justification only if their reliability is certified, a less stringent standard applies to perceptual experiences. For them to have justificational force, the absence of evidence of unreliability is sufficient. One problem for this position is that it seems unprincipled. Another problem arises from cases in which it intuitively seems that a perceptual experience lacks justificational force because of missing evidence of reliability.

Here is a candidate for a case like that. Suppose Ted lost his hearing because of neural damage caused by an infection. An ingenious neurosurgeon invented a neuro-chip that, when implanted in his brain, will restore Ted's hearing. Unfortunately, the neurosurgeon insists on a strange method of selecting a particular chip for Ted. Prior to the procedure of implanting the chip in Ted's brain, a ball will be randomly drawn from an urn. The urn has 10,000 balls each of which carries a chip inside. The reliability of the chips ranges from $1 \%$ to $100 \%$. Ted has no idea how many of each of the 100 different types of chips are in the urn. Neither the surgeon nor Ted will know the reliability of the chip that was drawn. Ted agrees to undergo the procedure. After a chip is implanted, Ted has his first auditory experience. He hears the sound of a trumpet. If Ted's experience is accurate, the sound is produced by an external source. If Ted's experience is hallucinatory, the sound was produced solely by the chip. ${ }^{31}$

In this case, Ted has no evidence to think that his neuro-chip is reliable. Nor does he have evidence that his chip is unreliable. He therefore has no evidence that his present auditory experience is reliable, and he has no evidence that it is unreliable. The question is: Does Ted's auditory experience have justificational force for him? According to conservatism $_{\mathrm{SE}}$, it does. ${ }^{32}$ According to meta-evidentialism, it does not. If you share the

\footnotetext{
31 Thanks to Paul Draper for suggesting the lottery-type aspect of this case. For a similar example, see the echolocation case in Steup 2004.

32 Suppose, upon experience the trumpet, Ted forms the belief that there is an actual, external trumpet sound he is hearing. What should dogmatists and SE-conservatives say about the justificational status of Ted's belief? It would be tempting for them to say that Ted's belief is not justified because it is defeated. But what's the defeater? Clearly there is no rebutting defeater. If Ted has as defeater, it would have to be an underminer. Now, undermining defeaters attack the reliability of the belief source. Since Ted has no evidence to think that his experience is unreliable, it would seem he lacks an undermining defeater. But if he has neither a rebutting nor
} 
intuition that Ted's experience is not a source of justification for him, the case gives you a reason to prefer meta-evidentialism to conservatism ${ }_{\mathrm{SE}}$.

There is an alternative way to interpret the case. This interpretation begins with the premise that, relative to Ted's total evidence, the probability that his auditory experience is accurate is 0.5. This premise is not uncontroversial. It might be argued that, given the details of Ted's overall epistemic situation, he simply has no basis for assigning any probability to his experience's being accurate. Let us bracket this worry. The alternative interpretation continues as follows. Since Ted knows that, given his total evidence, there is only a 0.5 probability that his experience is accurate, his total evidence indicates that his experience is unreliable. Here we have another problematic premise. We might hold instead that unreliability is to be identified with a success rate ranging from $0-49 \%$, reliability with a success rate ranging from $51-100 \%$, and that a success rate of $50 \%$ marks the middle ground where the mechanism in question is neither reliable nor unreliable. Let us bracket that worry as well. According to the argument under consideration, Ted actually has evidence of unreliability, contrary to the original reading of the case. Now the arguably implausible outcome is avoided. About the case thus interpreted, advocates of conservatism $\mathrm{SE}_{\mathrm{E}}$ can agree that Ted's experience fails to have justificational force for him.

The alternative way of interpreting the case is not a good way of defending conservatism $_{\mathrm{SE}}$. Here is the crucial premise of this line of reasoning:

(UR) If I have an experience $E$ and I know that, given my total evidence, the probability of E's being accurate is 0.5 , then my total evidence indicates that $E$ is unreliable.

If (UR) is true, then the only way for my total evidence to not indicate that $E$ is unreliable is for my total evidence to raise the probability of E's being accurate above 0.5. But then my total evidence indicates that $E$ is (at least minimally) reliable. Put differently, if (UR) is true, then the only way to not have evidence of unreliability is to have evidence of reliability. Now, if (UR) is true, then conservatism $\mathrm{SE}_{\mathrm{E}}$ tells us that $E$ has justificational force only if I my total evidence indicates that $E$ is (at least minimally) reliable. The alternative reading of the case, then, produces the result that conservatism $\mathrm{SE}$ turns into meta-evidentialism. This makes it difficult to see why the alternative reading should be of any help to conservatism $\mathrm{SE}_{\mathrm{S}}$.

an undermining defeater, it follows that his belief is justified. Given the details of the case, this does not look like a plausible outcome. 
Examples like that of Ted and his neuro-chip are strengthened when combined with the premise that justification is expected to be a path to truth. In the case as described, it is difficult to see any basis for Ted to think that his auditory experience is a path to truth. It clearly fails to make it probable that the sound he is hearing comes from an external source. So if we hold that justification should be a guide to truth, it is not easy to see why we should think that Ted's auditory experience has justificational force for him.

To sum up, the meta-evidentialist case against conservatism $\mathrm{SE}_{\mathrm{S}}$ follows the same pattern as the conservative case against dogmatism. It is based on:

i. cases involving witnesses and instruments; what's distinctive about them is that there's evidence of neither reliability or unreliability.

ii. cases involving perceptual experiences in which there's evidence of neither reliability nor unreliability.

iii. the premise that we expect justification to be a path to truth.

To me, the case seems strong. I think meta-evidentialism is more plausible than conservatism.

\section{Problems for meta-evidentialism}

If we are internalists and take seriously the expectation that justification provide us with a path to truth, then meta-evidentialism seems to be the place where the argument leads us. Yet meta-evidentialism is hardly a place where epistemologists can rest comfortably.

Challenges abound. I will conclude by considering the most serious ones and indicate how I think meta-evidentialists should respond.

First, suppose, modeled after BonJour's erstwhile coherentism, we take metaevidentialism to be committed to the following principle:

(BR) If you have a perceptual experience as of $p$ and that experience gives you justification for believing $p$, then you are justified in believing that that experience is reliable. ${ }^{33}$

According to (BR), perceptual justification requires justified beliefs about perceptual reliability. Such beliefs inevitably rely themselves on perceptual justification. BonJourean coherentism, therefore, generates an infinite regress and thus renders perceptual justification

33 See BonJour 1985, p. 117 ff. 
impossible. Meta-evidentialists are well advised to reject (BR), that is, to insist that perceptual justification does not require beliefs about reliability but merely evidence of reliability.

Second, critics of meta-evidentialism will want to know what evidence of reliability consist of. To a large part, it is track record evidence. When you ask yourself whether your perceptual experiences have served you well in the past, your memory will tell you that they have. But this is helpful only if you have evidence that your memory is reliable. Such evidence can only come from memory itself. Moreover, when your memory tells you that your perceptual experiences have served you well, what your memory makes available to you are just past perceptual experiences confirming each other. It turns out, then, that it is impossible to have evidence of perceptual reliability without relying on memory and perception to confirm the reliability of memory and perception. In short, the only way to acquire evidence of perceptual reliability is through evidential self-certification. This is a serious problem for meta-evidentialism. It should not be assumed too quickly, however, that evidential self-certification is epistemically pernicious. ${ }^{34}$

Assuming self-certification can be benign, does meta-evidentialism allow for knowledge of perceptual reliability? Alston has argued that, for externalists, reliability knowledge is unproblematic. If the belief that perception is reliable is itself reliably produced (and happens to be true), then, on reliabilism, this belief is an instance of knowledge. Meta-evidentialists are committed internalists and thus cannot exercise the reliabilist option. They can, however, make a foundationalist move. They could argue that memorial beliefs can be basic. If you have a memory impression that you had cereal for breakfast, and you have evidence of memorial reliability, then you have justification for believing that you had cereal for breakfast, and this justification does not come from any beliefs. Likewise, if you remember that your perceptual experiences have a good track record, and you have evidence of memorial reliability, then you have justification for believing that your perceptual experiences are reliable, and this justification does not come from or rest on any beliefs about perceptual reliability. Thus, in essence, goes the meta-evidentialist account of how one can acquire knowledge of perceptual reliability.

While Alston thinks that, for externalists, knowledge of perceptual reliability is easy to acquire, he claims that it is, for internalists and externalists alike, impossible to succeed in the

\footnotetext{
34 In Steup 2013, I argue that epistemic circularity can be benign. See also Vogel 2014. He argues that it's
} possible for evidence $\mathrm{E}$ to be evidence for the proposition that $\mathrm{E}$ is not misleading. 
attempt to show-i.e. successfully argue for the conclusion — that one's perceptual experiences are reliable. Any such attempt, according to Alston, will be infected with epistemic circularity. ${ }^{35}$ Epistemic circularity occurs when you cannot argue for a conclusion without using premises that can be justified only by appeal to the very conclusion you are aiming at. This is what's going on in the attempt to show that perception is reliable. If you wish to argue for the conclusion that perception is reliable, you need justified premises. Unfortunately, you cannot have the needed justified premises without relying on perception to begin with - a reliance that is rational only if you have already justification for taking perception to be reliable.

I think that Alston is right when he claims that arguments for reliability are unavoidably epistemically circular. Alston also thinks that epistemic circularity is always vicious. If he is right about that as well, reliabilists and meta-evidentialists are in the same boat. They cannot show that the conditions of perceptual justification are satisfied. Since dogmatists and advocates of conservatism $\mathrm{SE}$ require neither actual reliability nor evidence of reliability for perceptual justification, they have the advantage here. Their views raise no obstacle to showing that the conditions of perceptual justification are satisfied. But this dialectical advantage rests on the assumption that epistemic circularity is necessarily bad. If this assumption is false, then reliabilists and meta-evidentialists, too, can show that our perceptual beliefs are justified. ${ }^{36}$

35 See Alston 1993.

${ }^{36}$ I wish to thank two anonymous referees for their excellent feedback on this paper. 


\section{Bibliography}

Alston, William. 1989. Epistemic Justification. Essays in the Theory of Knowledge. Ithaca, New York: Cornell University Press.

Alston, William. 1993. The Reliability of Sense Perception. Ithaca, New York: Cornell University Press.

Alston, William. 1999. "Perceptual Knowledge.” In John Greco and Ernest Sosa (eds.), The Blackwell Guide to Epistemology (Malden, MA: Blackwell Publishers), pp. 223-242.

BonJour, Laurence. 1985. The Structure of Empirical Knowledge. Cambridge: Harvard University Press.

Brogaard, Berit. 2013. “Phenomenal seemings and sensible dogmatism.” In Tucker 2013, pp. 270-289.

Chisholm, Roderick. 1966. Theory of Knowledge ( $1^{\text {st }}$ edition). Englewood Cliffs, New Jersey: Prentice Hall.

Chisholm, Roderick. 1989. Theory of Knowledge ( ${ }^{\text {rd }}$ edition). Englewood Cliffs, New Jersey: Prentice Hall.

Cohen, Stewart. 2002. "Basic knowledge and the problem of easy knowledge." Philosophy and Phenomenological Research 65: 309-29.

DeRose, Keith. 1995. Solving the skeptical problem. The Philosophical Review 104: 1-52.

Dodd, Dylan and Zardini, Elia (eds.). 2014. Scepticism \& Perceptual Justification. Oxford:

Oxford University Press.

Feldman, Richard. 2003. Epistemology. Upper Saddle River, New Jersey: Pearson.

Foley, Richard. 1983. "Epistemic conservatism.” Philosophical Studies 443: 165-82.

Fumerton, Richard. 2007. "Epistemic conservatism: Theft or honest toil?” In Tamar Szabo Gendler \& John Hawthorne (eds.), Oxford Studies in Epistemology (Oxford: Oxford University Press), pp. 63-86.

Huemer, Michael. 2001. Skepticism and the Veil of Perception. Lanham, Maryland: Roman and Littlefield.

Huemer, Michael. 2013. “Phenomenal conservatism über alles.” In Tucker (ed.) 2013: 32849.

Lehrer, Keith. 1990. Theory of Knowledge. Boulder: Westview Press.

Markie, Peter. 2013 “Searching for true dogmatism.” In Tucker (ed.) 2013: 248-69. 
Pollock, John. 1974. Knowledge and Justification. Princeton, New Jersey: Princeton University Press.

Pollock, John L. 1986. Contemporary Theories of Knowledge. Totowa, NJ: Rowman and Littlefield. Pryor, James. 2000. “The skeptic and the dogmatist.” Nous 34: 517-549.

Pryor, James. 2004. “What's wrong with Moore’s argument?” Philosophical Issues 14, 2004.

Pryor, James. 2013. "Problems for Credulism.” In Tucker 2013: 89-131.

Steup, Matthias. 2004. “Internalist Reliabilism,” Pbilosopbical Issues 14, 2004, pp. 404-425.

Steup, Matthias. 2013. “Is Epistemic Circularity Bad?” Res Philosophica 90 (2013): 215-235.

Tucker, Chris. 2010. “Why open-minded people should endorse dogmatism.” Philosophical Perspectives 24: 529-545.

Tucker, Chris (ed.). 2013. Seemings and Justification. New York: Oxford University Press.

Vogel, Jonathan. 2014. “E \& $\neg$ H.” In Dylan Dodd and Elia Zaardini (eds), Scepticism and Perceptual Justification. Oxford: Oxford University Press: 87-107.

Wright, Crispin. 2004. On epistemic entitlement: warrant for nothing (and foundations for free?). Aristotelian Society Supplement 78: 167-212.

Wright, Crispin. 2014. “On epistemic entitlement (2): Welfare State Epistemology,” in: Dodd and Zardini (eds.): 213-47.

Zardini, Elia. 2014. "Confirming the less likely, discovering the unknown: dogmatismssurd and doubly surd, natural, flat and doubly flat.” In Dodd and Zardini 2014, pp. 33-70. 